\title{
THE EMPIRICAL RELATIONSHIP BETWEEN STOCK RETURNS AND TRADING VOLUME: THE CASE OF POLISH COMPANIES
}

\author{
[Empirická vazba mezi akciovými výnosy a objemem obchodování: aplikace na \\ polské společnosti]
}

\author{
Marie Ligocká ${ }^{1}$ \\ ${ }^{1}$ Vysoká škola ekonomická v Praze, nám. W. Churchilla 1938/4, 13067 Praha 3 - Žižkov \\ Email:marie.ligocka@vse.cz
}

\begin{abstract}
Volume indicators are often combined with information about stock prices development. Technical analysts use trading volume as a support tool to confirm trend directions. I focused on the Warsaw Stock Exchange that is one of the most dynamically growing capital markets in Europe and I tried to detect if trading volume can be used as a support tool the technical analysis on this stock market. Data of 67 companies was analysed in 2008 - 2018 using the Granger causality. The findings show, both the correlation and the Granger causality was determined in most cases for investment sector and real estate sector that could be caused, for example by higher share on GDP of these sectors in comparison with other analysed industries, market position of companies, and by interest of investors. However, it seems trading volume as a support tool of the technical analysis is more relevant on more developed and high liquidity markets.
\end{abstract}

Keywords: Granger causality, stock returns, trading volume, Warsaw Stock Exchange.

JEL classification: L6, C3, O52

Received: 17.10.2019; Reviewed: 21.10.2019; 23.10.2019; Accepted: 30.10.2019

\section{Introduction}

The trading volume is often combined with development of the stock returns or stock prices because volume indicators could be related partially to the strengths or weaknesses of the market and behaviour of investors. The trading volume is not only part of the technical analysis, but it is a psychological factor due to the reflection of sentiment of the investors (Veselá 2011). According to the technical analysts the fundamental factors are insufficient for the stock analysis. Gündüz and Hatemi-J (2005) argue that there are theoretically stock prices changes when new information arrives. Therefore, if trading volume is linked to the information flow entering a market, this also implies the existence of a significant relationship between trading volume and stock prices.

Empirical literature discusses the topic mainly on developed and high liquidity markets but there is also a focus on European stock markets. Due to the fact that the Warsaw Stock Exchange that is one of the most dynamically growing capital markets in Europe and the market could be an investment opportunity for investors and the object of analysts' interest, the paper is focused on exploring if trading volume could be used as a support tool of the technical analysis on Polish stock market. The Warsaw Stock Exchange is the largest stock exchange in the Central Europe with 465 listed companies and the total market capitalization 1,128.51 Bn. PLN in December 2018. There are traded 359 companies with market capitalization $1,113726.50 \mathrm{Bn}$. PLN on the main market and parallel market was characterized by 106 traded companies with market capitalization 14,781.58bil. PLN in December 2018. The total turnover value of the Warsaw Stock Exchange was approximately 211.850 Bn. PLN in 2018. Measured by the number of IPOs, Warsaw was the 3rd largest in Europe after London and Stockholm. The strong interest of local and regional companies in 
being listed on the Warsaw Stock Exchange has for many years strengthened the position of the Exchange as one of Europe's leading exchanges, and it is CEE's top market by the number of listed companies (GPW 2019). The higher number of initial public offers of stocks is related to the rise of the absolute value of trades; that should cause the increase of the market liquidity. The higher market liquidity could present the increase of investors' interest in securities traded on the market; moreover, analytics could be interested about development of market trend and they could use the trading volume as a support tool of the technical analysis (Veselá 2011).

The objective of the paper is to examine the relationship between the trading volume and stock returns of 67 Polish companies listed on the Warsaw Stock Exchange. The selection of companies is based on similar business profile of companies and the highest number of companies in each sector, according to these criteria there are analysed 5 sectors, specifically clothing industry, food industry, investment sector, machine industry and real estate sector. The benefit of the paper is to extend empirical literature focused on analyse of relationship between trading volume and stock returns of companies listed on Eastern European stock markets specifically Polish stock market which is analysed. So far published studies, for example Gurgul et al. (2005) and Bohl and Henke (2003), used smaller sample of analysed companies, and due to the analyse of sample period 2008 - 2018 there is possible to provide current knowledge in this research yield on Polish stock market. The article is divided into several sections: A Review of the Literature (1) follows the Introduction. Then, the section Data and Methodology (2) is presented, followed by Results and Discussion (3); with the final section related to Conclusion.

\section{Review of the Literature}

The technical analysis is the oldest stock market analysis approach to stock prices development predictions and future trends. The information about stock prices changes and the trading volume is often used as a support tool (Musílek 2002; Veselá 2011); therefore, a lot of studies have been conducted to examine the relationship between stock prices or stock returns and trading volume to analyse the possibility of using the trading volume as a support tool of the technical analysis. The Review of the Literature is focused mainly on stock returns of European companies and its relation to trading volume in terms of the objective of analysis, which is Poland.

The relationship between stock returns and trading volume was investigated by Chen et al. (2001) who analysed nine national markets including European countries. The results of the study show that there is positive relationship between trading volume and stock returns in France, Netherland and Switzerland; but there was not detected relationship between trading volume and stock returns in the UK and Italy. In contrast, with Chen et al. (2001), Iqbal and Riaz (2015) show both positive and negative relationship between the traded volume of stocks and their returns. They examined the association among daily traded volume of stocks, volatility and daily stock returns with using the index FTSE 100. Results of the study show that past returns affected volume but there was no evidence that past trading volume affected stock returns so this suggests, no feedback association among returns and traded volume by considering market as well as stocks. The same as Chen et al. (2001) and Iqbal and Riaz (2015) also Rotila et al. (2015) investigated the relation between the stock return and trading volume. But their findings show different results because a relation existed only under certain conditions, and there was an unidirectional relation rather than a bidirectional one. Due to the relation between the stock returns and trading volume after the crisis, the results bring to light that the relation exists but only in the case of small size stocks and those traded in the EU 
zone, where the returns depend on both trading volume and their past values. Not only Rotila et al. (2015) but also Brüggemann et al. (2014) show there was an unidirectional relation. They analysed relationship between trading volume and stock returns for 16 European countries. They found out that stock returns have a significance in influence on trading volume, but there is no evidence for their influence of trading volume on returns. A difference in results is evident in the study of Gündüz and Hatemi-J (2005) who explored the causal relationship between stock prices and volume figures for stock markets in the Czech Republic, Hungary, Poland, Russia, and Turkey. The results show there is no causal relationship between the factors in the Czech Republic, there is a bidirectional causality in Hungary, and an unidirectional causality was detected in Poland, Russia and Turkey.

In contrast, with findings of Rotila et al. (2015) and Brüggemann et al. (2014) there are presented results of Tudor (2008). Tudor (2008) investigated both the return-volume and volatility-volume movements on the Bucharest Stock Exchange, in order to evaluate the impact of changes in stock market liquidity on stock returns and on volatility of returns. The findings show existence of linear causality from returns to volume and also from volume to volatility. However, some studies show opposite findings that there is no relationship between stock returns and trading volume. For example, Lee and Rui (2002) explored the relation between trading volume and stock returns on the largest stock markets including London. The results show there is not any Granger causality between stock returns and trading volume. The findings also show that the US market variables have an extensive predictive power for the UK and Japanese financial market variables; particularly US trading volume contains information about Japanese and the UK financial variables. The same results as study of Lee and Rui (2002) show findings of Gurgul et al. (2005). Gurgul et al. (2005) analysed the relationship between stock returns and trading volume of Polish companies included in WIG 20. The results indicate that there is no empirical support for a relationship between stock returns and trading volume. But their calculations provide evidence for a significant contemporaneous interaction between return volatility and trading volume.

Figure 1: Research Design

\begin{tabular}{|c|c|c|}
\hline & & Output \\
\hline Input & Process & \multirow[b]{2}{*}{$\begin{array}{l}\text { - There is Granger causality between TV } \\
\text { and SR. } \\
\text { - There is not Granger causality between } \\
\text { TV and SR. } \\
\text { - There is Granger causality in opposite } \\
\text { direction. }\end{array}$} \\
\hline $\begin{array}{l}\text { - Trading volume } \\
\text { (TV). } \\
\text { - Stock } \\
\text { returns/stock } \\
\text { prices (SR). }\end{array}$ & $\begin{array}{l}\text { - Review of the } \\
\text { Literature. } \\
\text { - Data mining. } \\
\text { - Analysis } \\
\text { (Correlation } \\
\text { analysis, } \\
\text { Grenger } \\
\text { Causality). }\end{array}$ & \\
\hline
\end{tabular}

Source: Own.

The similar findings as Lee and Rui (2002) and Gurgul et al. (2005) are demonstrated in the study of Bohl and Henke (2003) who examined the relationship between daily returns and trading volume for 20 Polish stocks. Their results show that in the majority of cases volatility persistence tends to disappear when trading volume is included in the conditional variance equation, which is in agreement with the findings of studies on developed stock markets. In relation to the findings of individual authors, the research design is defined in a Figure 1. 


\section{Data and Methodology}

The 67 companies listed on the Warsaw Stock Exchange are used. In particular, there are 12 clothing companies, 13 food companies, 12 investment companies, 16 machine companies and 14 real estate companies, as Table 1 shows. Data with a daily frequency is used for the period 1. 1. 2008 - 31. 12. 2018. The start year is 2008 because bigger amount of companies in examined sectors was quoted on the Warsaw Stock Exchange during the year 2007. The final year is elected 2018 to make the timeframe coherent and include yearlong data for each year included in the analysis. The setting of the analysis period allowed to include the largest possible number of companies in each sector. Data on stock prices is from the portal Stooq and the Warsaw Stock Exchange. The following criteria were defined to create the analysed sample: 1. The analysis is focused on Polish companies, and there are not included foreign companies listed on the Warsaw Stock Exchange due to the identical legislative regulations of business activities for companies; 2. The quotation of companies on the Warsaw Stock Exchange had to be in 2008 at the latest due to the including the largest possible number of companies and there is also required a similar business profile of companies; 3 . The 5 sectors are selected due to the relative equally distributed and similar number of analysed companies among the sectors under examination. There are lower numbers of companies in other sectors.

Table 1: Analysed Companies

\begin{tabular}{|l|l|l|l|l|}
\hline Clothing & Food & Investment & Machine & Real Estate \\
\hline Bytom & Ambra & Atlantis & Apator & Alta \\
\hline CCC & Atlanta Poland & Baltic Bridge & Fasing & BBI Development \\
\hline Ginorossi & Gobarto & Calatrava Capital & Famur & DOM Development \\
\hline Intrsppl & Grupa Żywiec & Capital Partners & Hydrotor & ECHO Investment \\
\hline LPP & Helio & Immobile & Lena Lighting & Elkop \\
\hline Monnari & Indykpol & Impera Capital & Mangata Holding & Globe Trade Centre \\
\hline Primamoda & Kruszwica & INC & Moj & J. W. Construction Holding \\
\hline Protektor & Makarony Polskie & Krezus & Primetech & LC Corp \\
\hline Prochnik & Pamapol & Magna Polonia & Rafamet & Octava \\
\hline Redan & Pepees & MCI Capital & Rawlplug & Polnord \\
\hline Sanwil & Seko & PME & Redwood & Ronson Development \\
\hline Vistula & Wawel & Rubicon Partners & Relpol & Soho Development \\
\hline & Wilbo & & Ursus & Triton Development \\
\hline & & & Urządzeń Kotłowych Stąporków & Wikana \\
\hline & & & Wielton & \\
\hline & & & Zpue & \\
\hline
\end{tabular}

Source: Own based on GPW, 2019. GPW Main Market [online] [vid. 1 June 2019]. Available from: <https://www.gpw.pl/list-of-companies>.

Data of stock prices are used to calculate the stock returns. Using of logarithmic stock returns is consistent with empirical literature, for example Iqbal and Riaz (2015), Brüggemann et al. (2014) and Bohl and Henke (2003). The calculation of logarithmic stock returns following equation shows:

$$
r_{t}=\ln \left(\frac{P_{t}}{P_{t-1}}\right) * 100
$$

where $r_{t}$ presents stock returns, $P_{t}$ is close price of stock and $P_{t-1}$ symbolizes open price of stock. Then, the stationarity of the time series was tested by the Augmented Dickey-Fuller (ADF) to verify whether the time series are stationary. The null hypothesis of ADF is defined as follows (Cipra 2008; Neusser 2016):

$$
H_{0}: \Delta y_{t}=\psi_{t-1}+\sum_{i=1}^{p} \gamma_{i} \Delta y_{t-i}+\varepsilon_{t}, \quad \psi=0
$$


where $p$ is an order of autoregressive polynomial, $\Delta$ presents difference operator, $t$ is time period, $\psi$ and $\gamma$ are regression parameters. $Y_{t}$ is dependent variable (stock returns and trading volume). Then, the data was subjected to the correlation analysis to determine a linear relationship between stock returns and the trading volume. The Pearson correlation coefficient, which is a parametric measure of dependence between variables, is calculated as (Cipra 2008; Pesaran 2015):

$$
\hat{\rho}_{Y X}=\frac{\sum_{t=1}^{T}\left(x_{t}-\bar{x}\right)\left(y_{t}-\bar{y}\right)}{\left[\sum_{t=1}^{T}\left(x_{t}-\bar{x}\right)^{2} \sum_{t-1}^{T}\left(y_{t}-\bar{y}\right)\right]^{1 / 2}}=\frac{S_{X Y}}{\left(S_{Y Y} S_{X X}\right)^{1 / 2}}
$$

where $X$ and $Y$ are observations of stock returns and trading volume, $\hat{\rho}_{Y X} \in\langle-1,1\rangle$. The correlation coefficient between $X$ and $Y$ is the same as the correlation coefficient between $Y$ and $X$. Furthermore, the analysis of the short-term causality of the relationship between stock returns and the trading volume is performed using the Granger test; the causal model in the mathematical equation is in accordance with Granger (1969):

$$
\begin{aligned}
& \Delta Y_{t}=\beta_{0}+\sum_{i=1}^{q} \beta_{1 i} \Delta Y_{t-i}+\sum_{i=1}^{q} \beta_{2 i} \Delta X_{t-i}+\varepsilon_{1 t} \\
& \Delta X_{t}=\varphi_{0}+\sum_{i=1}^{r} \varphi_{1 i} \Delta X_{t-i}+\sum_{i=1}^{r} \varphi_{2 i} \Delta Y_{t-i}+\varepsilon_{2 t}
\end{aligned}
$$

where $Y_{t}$ and $X_{t}$ symbolize stock returns and trading volume, respectively. Coefficient $t$ presents the time period, $\Delta$ means rate of growth or change of non-stationary variable, $\beta$ and $\varphi$ are estimated coefficients for stock returns and trading volume, $q$ and $r$ are the order of moving-average polynomial, $i$ is a number of the periods, $\varepsilon_{1 t}$ and $\varepsilon_{2 t}$ are uncorrelated stationary random variables. The objective of this test is to reject the $H_{0}$ : $\beta_{21}=\beta_{22}=\ldots=\beta_{2 q}=0$. This hypothesis implies that the trading volume do not Granger cause stock returns. Similarly, failing to reject $H_{0}: \varphi_{11}=\varphi_{12}=\ldots=\varphi_{1 r}=0$ suggests that stock returns do not Granger cause the trading volume. According to the Akaike information criterion, the Schwarz Criterion and the Hannan-Quinn information criterion is optimal lag length 2.

For example, Hiemstra and Jones (1994) claim that the causality test can provide useful information on whether knowledge of past stock price movements improves short-run forecasts of current and future movements in trading volume, and vice versa. Moreover, Dumitrescu and Hurlin (2012) show that the method is also useful for small sample properties and Sims (1975) confirms the Granger causality test may be the most natural framework for doing causality tests. It is also necessary to remark that Granger causality is different from real causality as Hui-wen (2006) demonstrated. The advantage of the Granger causality as a method is the frequency decomposition, which is usually informative when we deal with temporal data (Zou and Feng 2009). The Granger causality involves estimating a linear reduced-form vector autoregression and the presence of Granger causality and it is tested by evaluating the predictive power of one-time series for another as Hiemstra and Jones (1994) argue. 


\section{Results and Discussion}

First, correlation coefficients between the stock returns and the trading volume for clothing, food and investment companies are showen in Table 2. The stock returns of the clothing companies Bytom, Ginorossi, Intersppl, Monnari, Primamoda, Protektor, Redan, Sanwil and Vistula were significantly correlated with the trading volume. The correlation coefficients between the trading volume and stock returns of the companies CCC, LPP and Prochnik are not statistically significant. The stock returns of food companies Ambra, Atlanta Poland, Gobarto, Grupa Zywiec, Helio, Indykpol, Kruszwica, Makrony Polskie and Peppees were significantly correlated with the trading volume. The correlation coefficients between the trading volume and stock returns of the companies Pamapol, Seko, Wawel and Wilbo are not statistically significant. Further, the correlation coefficients between the stock returns of investment companies and trading volume are presented. The stock returns of the companies Atlantis, Capital Partners, Immobile, INC, Krezus, MCI Capital, PME and Rubicon Partners were significantly correlated with the trading volume. The positive value of correlation coefficients mean the rise of the trading volume should be related with increasing of stock returns; and the negative value of correlation coefficients reflect that the increase in value of trading volume should mean the decrease of the stock returns. The correlation coefficients between the trading volume and stock returns of the companies Baltic Bridge, Calatrava Capital, Impera Capital and Magna Polonia are not statistically significant.

Table 2: Correlation Coefficients between the Stock Returns of Clothing, Food and Investment Companies and Trading Volume

\begin{tabular}{|l|l|l|l|l|l|}
\hline Clothing & Food & \multicolumn{2}{l|}{ Investment } \\
\hline Company & Trading volume & Company & Trading volume & Company & Trading volume \\
\hline Bytom & $0.1809^{*}$ & Ambra & $0.0474^{* *}$ & Atlantis & $-0.1550^{*}$ \\
\hline CCC & 0.0098 & Atlanta Poland & $0.0517^{* *}$ & Baltic Bridge & 0.0217 \\
\hline Ginorossi & $0.0873^{*}$ & Gobarto & $0.0970^{*}$ & Calatrava Capital & 0.0024 \\
\hline Intrsppl & $0.1684^{*}$ & Grupa Żywiec & $0.0815^{*}$ & Capital Partners & $0.1172^{*}$ \\
\hline LPP & 0.0327 & Helio & $0.1432^{*}$ & Immobile & $0.0756^{*}$ \\
\hline Monnari & $0.1772^{*}$ & Indykpol & $0.0951^{*}$ & Impera Capital & 0.0297 \\
\hline Primamoda & $0.0634^{*}$ & Kruszwica & $0.0441^{*}$ & INC & $0.1296^{*}$ \\
\hline Protektor & $0.0519^{*}$ & Makarony Polskie & $0.1110^{*}$ & Krezus & $0.1419^{*}$ \\
\hline Prochnik & 0.0235 & Pamapol & 0.0070 & Magna Polonia & -0.0367 \\
\hline Redan & $0.1128^{*}$ & Pepees & $0.0851^{*}$ & MCI Capital & $0.0598^{*}$ \\
\hline Sanwil & $0.1088^{*}$ & Seko & 0.0185 & PME & $0.0714^{*}$ \\
\hline Vistula & $0.1520^{*}$ & Wawel & 0.0005 & Rubicon Partners & $-0.0676^{*}$ \\
\hline & & Wilbo & 0.0209 & & \\
\hline
\end{tabular}

Source: Authors' calculations.

The relationship between stock returns and trading volume was also tested with using the Granger causality test. According to the Akaike information criterion, Schwarz information criterion and Hannan-Quinn information criterion is optimal lag length 2. The correlation and the Granger causality is confirmed between the trading volume and the stock returns of the clothing companies Bytom, Primamoda, Sanwil, and Wistula as Table 3 presents. The findings for food companies detected the Granger causality between the trading volume and the stock returns of the companies Ambra, Gobarto, Indykpol, and Pepees, where the linear relationship between variables is also determined. Then, the correlation and the Granger causality is confirmed between the trading volume and the stock returns of the investment companies Atlantis, Capital Partners, Immobile, INC, and Krezus. The existence of the Granger causality between variables is not always related to the companies with the highest trading volumes and market capitalization; that could be related to the fact the correlation coefficients between variables are very near to the zero and co-movements of variables didn't have to be very strong. There could be different factors that had an impact on existence of the 
Granger causality between trading volume and stock returns, for example: the tradition of the companies on the market, relatively stable development of business activities of the companies, the perspective of the sectors, the sector cycle, and competitors. Investors also could have the important role; there is also possibility that high number of small investors could be related with higher sentiment of them, and trading volume changes could reflect false signals.

There was also detected the causality in the opposite direction going from the stock returns of the clothing companies Intersppl, Monnari, Sanwil and Vistula to the trading volume, where is also existence of linear relationship between variables confirmed. And then there was determined correlation and causality in the opposite direction going from the stock returns of the food companies Gobarto, Grupa Zywiec, Helio, Indykpol, and Pepees and the investment companies Atlantis, INC, Krezus and MCI Capital to the trading volume. The existence of the causality in the opposite direction could be caused by the fact, there are many variables that can affect the stock returns, positively or negatively; these factors could have an impact on investors' investment decisions, and that is reflected on the trading volume, for example: macroeconomic variables, industry specifics, corporate governance factors, financial characteristics of companies. There was also determined no relationship between selected variables for some companies. The findings of no relationship could be caused for example by lower liquidity of titles and related lower interest of investors, shorter existence of companies, lower markets share, lower importance in the industry, and question of future development of companies.

Table 3: Results of Granger Causality Test for Clothing, Food and Investment Companies

\begin{tabular}{|c|c|c|c|c|c|}
\hline Company & F-statistic & Company & F-statistic & Company & F-statistic \\
\hline \multicolumn{2}{|l|}{ Bytom } & \multicolumn{2}{|l|}{ Ambra } & \multicolumn{2}{|l|}{ Atlantis } \\
\hline $\mathrm{TV}=/ \Rightarrow>\mathrm{SR}$ & $3.0118 * *$ & $\mathrm{TV}=/ \Rightarrow \mathrm{SR}$ & $6.0074 *$ & $\mathrm{TV}=/ \Rightarrow>\mathrm{SR}$ & $16.4152 *$ \\
\hline \multicolumn{2}{|l|}{$\mathrm{CCC}$} & \multicolumn{2}{|l|}{ Gobarto } & $\mathrm{SR}=/ \Rightarrow>\mathrm{TV}$ & $10.3494 * *$ \\
\hline $\mathrm{SR}=/=>\mathrm{TV}$ & $4.1077 * *$ & $\mathrm{TV}=/=>\mathrm{SR}$ & $4.8671^{*}$ & \multicolumn{2}{|l|}{ Baltic Bridge } \\
\hline \multicolumn{2}{|l|}{ Intrsppl } & $\mathrm{SR}=/ \Rightarrow \mathrm{TV}$ & $12.3578 * *$ & $\mathrm{TV}=/ \Rightarrow>\mathrm{SR}$ & $4.1763 * *$ \\
\hline $\mathrm{SR}=/=>\mathrm{TV}$ & $13.6486 *$ & \multicolumn{2}{|l|}{ Grupa Żywiec } & \multicolumn{2}{|c|}{ Capital Partners } \\
\hline \multicolumn{2}{|l|}{ Monnari } & $\mathrm{SR}=/ \Rightarrow>\mathrm{TV}$ & $2.4994 * * *$ & $\mathrm{TV}=/=>\mathrm{SR}$ & $8.6501 *$ \\
\hline $\mathrm{SR}=/ \Rightarrow \mathrm{TV}$ & $3.2249 * *$ & \multicolumn{2}{|l|}{ Helio } & \multicolumn{2}{|l|}{ Immobile } \\
\hline \multicolumn{2}{|l|}{ Primamoda } & $\mathrm{SR}=/=>\mathrm{TV}$ & $3.2440 * *$ & $\mathrm{TV}=/=>\mathrm{SR}$ & $3.2187 * *$ \\
\hline $\mathrm{TV}=/=>\mathrm{SR}$ & $13.6262 *$ & \multicolumn{2}{|l|}{ Indykpol } & \multicolumn{2}{|c|}{ Impera Capital } \\
\hline \multicolumn{2}{|l|}{ Prochnik } & $\mathrm{TV}=/ \Rightarrow \mathrm{SR}$ & $6.5551^{*}$ & $\mathrm{SR}=/ \Rightarrow \mathrm{TV}$ & $5.9746^{*}$ \\
\hline $\mathrm{TV}=/ \Rightarrow>\mathrm{SR}$ & $9.9222 * *$ & $\mathrm{SR}=/ \Rightarrow \mathrm{TV}$ & $7.8485^{*}$ & \multicolumn{2}{|l|}{ INC } \\
\hline $\mathrm{SR}=/=>\mathrm{TV}$ & $5.2564 *$ & \multicolumn{2}{|l|}{ Pamapol } & $\mathrm{TV}=/=>\mathrm{SR}$ & $7.3346^{*}$ \\
\hline \multicolumn{2}{|l|}{ Redan } & $\mathrm{SR}=/=>\mathrm{TV}$ & $2.9599 * * *$ & $\mathrm{SR}=/=>\mathrm{TV}$ & $19.0072 *$ \\
\hline $\mathrm{SR}=/ \Rightarrow \mathrm{TV}$ & $10.3255^{* *}$ & \multicolumn{2}{|l|}{ Pepees } & \multicolumn{2}{|l|}{ Krezus } \\
\hline \multicolumn{2}{|l|}{$\begin{array}{l}\text { Sanwil } \\
\end{array}$} & $\mathrm{TV}=/=>\mathrm{SR}$ & $15.7992 *$ & $\mathrm{TV}=/=>\mathrm{SR}$ & $4.3173 * *$ \\
\hline $\mathrm{TV}=/=>\mathrm{SR}$ & $3.1602 * * *$ & $\mathrm{SR}=/=>\mathrm{TV}$ & $9.8464 * *$ & $\mathrm{SR}=/=>\mathrm{TV}$ & $9.4564 * * *$ \\
\hline $\mathrm{SR}=/=>\mathrm{TV}$ & $3.2183 * * *$ & \multicolumn{2}{|l|}{ Wawel } & \multicolumn{2}{|c|}{ Magna Polonia } \\
\hline \multicolumn{2}{|l|}{ Vistula } & $\mathrm{TV}=/=>\mathrm{SR}$ & $3.2410 * *$ & $\mathrm{TV}=/=>\mathrm{SR}$ & $14.8042 *$ \\
\hline $\mathrm{TV}=/=>\mathrm{SR}$ & $6.9409 *$ & \multicolumn{2}{|l|}{ Wilbo } & \multicolumn{2}{|l|}{ MCI Capital } \\
\hline \multirow[t]{2}{*}{$\mathrm{SR}=/=>\mathrm{TV}$} & $9.1674 *$ & $\mathrm{TV}=/ \Rightarrow \mathrm{SR}$ & $10.4444 * *$ & $\mathrm{SR}=/ \Rightarrow \mathrm{TV}$ & $3.10587 * *$ \\
\hline & & $\mathrm{SR}=/=>\mathrm{TV}$ & $18.2707 *$ & & \\
\hline
\end{tabular}

Source: Authors' calculations. Note: *, ** and *** denote significance at the $1 \%, 5 \%$ and $10 \%$ levels. TV denotes trading volume and SR denotes stock returns.

Further, the correlation coefficients between the stock returns of machine and real estate companies and trading volume in Tab. 4 follow. The statistically significant correlation coefficients are detected between the trading volume and stock returns of the companies Apator, Famur, Lena Lighting, Mangata Holding, Primetech, Rafamet, Relpol, Ursus, Urządzeń Kotłowych Stąporków, Wielton, and Zpue. The correlation coefficients between the 
trading volume and stock returns of the companies Fasing, Moj, Rawlplug and Redwood are statistically insignificant. Moreover, the stock returns of the real estate companies Alta, BBI Development, ECHO Investment, Elkop, J. W. Construction Holding, LC Corp, Octava, Polnord, Ronson Development, Soho Development, Triton Development and Wikana were significantly correlated with trading volume. The correlation coefficients between the trading volume and stock returns of the companies DOM Development and Globe Trade Centre are not statistically significant. Values of correlation coefficients are both, positive and negative. The positive results show the increase of the trading volume should mean the increasing of the stock returns, and the negative value of correlation coefficients present that the rise of the trading volume should cause the decrease of the stock returns. But values of the correlation coefficients for all sectors are very near to the zero; this could mean the relationships between co-movements of variables are not so strong. The negative and positive values of correlation coefficients are consistent with findings of Iqbal and Riaz (2015) that showed there can be both positive and negative relationship between the trading volume and stock returns.

Table 4: Correlation Coefficients between the Stock Returns of Machine and Real Estate Companies and Trading Volume

\begin{tabular}{|l|l|l|l|}
\hline Machine & Trading volume & Company & \multicolumn{2}{l|}{} \\
\hline Company & $0.0646^{*}$ & Alta & Trading volume \\
\hline Apator & $0.1109^{*}$ & BBI Development & $0.1148^{*}$ \\
\hline Famur & 0.0308 & DOM Development & $0.0545^{*}$ \\
\hline Fasing & $0.0588^{*}$ & ECHO Investment & 0.0212 \\
\hline Hydrotor & $0.1022^{*}$ & Elkop & $0.0650^{*}$ \\
\hline Lena Lighting & $0.0482^{*}$ & Globe Trade Centre & $-0.0750^{*}$ \\
\hline Mangata Holding & -0.0256 & J. W. Construction Holding & 0.0287 \\
\hline Moj & $0.1230^{*}$ & LC Corp & $0.0904^{*}$ \\
\hline Primetech & $0.0568^{*}$ & Octava & $0.0743^{*}$ \\
\hline Rafamet & 0.0236 & Polnord & $0.1368^{*}$ \\
\hline Rawlplug & 0.0129 & Ronson Development & $0.0997^{*}$ \\
\hline Redwood & $0.0966^{*}$ & Soho Development & $0.0831^{*}$ \\
\hline Relpol & $0.1193^{*}$ & Triton Development & $0.0735^{*}$ \\
\hline Ursus & $0.0453^{*}$ & Wikana & $0.1067^{*}$ \\
\hline Urządzeń Kotłowych Stąporków & $0.0955^{*}$ & & \\
\hline Wielton & $-0.0545^{*}$ & & \\
\hline Zpue & & &
\end{tabular}

Source: Authors' calculations.

The findings of Granger causality for machine and real estate companies in Tab. 5 are given. The Granger causality and linear relationship between analyse factors are determined between the trading volume and the stock returns of machine companies Famur, and Lena Lighting. The existence of the Granger causality and correlation is also confirmed between the trading volume and the stock returns of the real estate companies Alta, BBI Development, Elkop, J. W. Construction Holding and Ronson Development. The factor that could affect results was the correlation coefficients, which are very near to the zero; this could mean the comovements of variables were not so strong. This could be related to the fact the Granger causality between trading volume and stock returns is prevailed on more liquid titles but it was not a rule. And there were different factors that affect the relationship between trading volume and stock prices, for example sentiment of investors, the rational and non-rational investment decisions, the tradition of the companies on the market, the position and importance in the industry, the interest of investors about individual stock titles, the perspective of the sectors and individual companies, the sector cycle, competitors, and the size of the market. 
There was also found the causality in the opposite direction going from the stock returns of the machine companies Hydrotor, Lena Lighting, Relpol, Ursus, Urządzeń Kotłowych Stąporków and Zpue, and real estate companies ECHO Investment, J. W. Construction Holding, LC Corp, Soho Development and Wikana to the trading volume, where the linear relationship between factors is also detected. The causality in the opposite direction is attributed to many factors that could affect stock returns. The existence of Granger causality in opposite direction going from the stock returns on trading volume could be caused by fact the stock prices demand is influenced by many factors, for example by macroeconomic variables, industry specifics, corporate governance factors, financial characteristics of companies. These variables could affect trading volume. There was also detected no Granger causality between trading volume and stock returns for some companies. The findings of no relationship could be caused for example by lower liquidity of titles and related lower interest of investors, shorter existence of companies, lower markets share, lower importance in the industry, and question of future development of companies. For analysed sectors, the results of the Granger causality in Table 3 and Table 5 show, both the correlation and Granger causality was determined in most cases for investment and real estate sectors that could be caused, for example by higher share on GDP of these sectors in comparison with other analysed industries, market position of companies, interest of investors about finance sector for portfolio diversification, industry life cycle, competition in industry, and business cycle sensitivity. Simultaneously, in sectors (investment industry and real estate industry) where is evident a higher number of observations of Granger causality between trading volume and stock returns, there is usually determined lower number of observations of causality in opposite direction going from stock returns on trading volume, and vice versa. It seems that there is better perspective of using trading volume as support tool of technical analysis in investment and real estate industry then in food, clothing and machine industry.

Table 3: Results of Granger Causality Test for Machine and Real Estate Companies

\begin{tabular}{|c|c|c|c|}
\hline Company & F-statistic & Company & F-statistic \\
\hline \multicolumn{2}{|l|}{ Famur } & \multicolumn{2}{|l|}{ Alta } \\
\hline $\mathrm{TV}=/=>\mathrm{SR}$ & $3.0044 * *$ & $\mathrm{TV}=/=>\mathrm{SR}$ & $4.2788 * *$ \\
\hline \multicolumn{2}{|l|}{ Hydrotor } & \multicolumn{2}{|c|}{ BBI Development } \\
\hline $\mathrm{SR}=/=>\mathrm{TV}$ & $4.0116^{* *}$ & $\mathrm{TV}=/=>\mathrm{SR}$ & $14.2323 *$ \\
\hline \multicolumn{2}{|l|}{ Lena Lighting } & \multicolumn{2}{|c|}{ ECHO Investment } \\
\hline $\mathrm{TV}=/=>\mathrm{SR}$ & $3.7835 * *$ & $\mathrm{SR}=/=>\mathrm{TV}$ & $3.2822 * *$ \\
\hline $\mathrm{SR}=/=>\mathrm{TV}$ & $2.6360 * * *$ & \multicolumn{2}{|l|}{ Elkop } \\
\hline \multicolumn{2}{|l|}{ Moj } & $\mathrm{TV}=/=>\mathrm{SR}$ & $2.6739 * * *$ \\
\hline $\mathrm{TV}=/=>\mathrm{SR}$ & $19.2138 *$ & \multicolumn{2}{|c|}{ Globe Trade Centre } \\
\hline $\mathrm{SR}=/=>\mathrm{TV}$ & $7.2689^{*}$ & $\mathrm{SR}=/=>\mathrm{TV}$ & $4.7872 *$ \\
\hline \multicolumn{2}{|l|}{ Rawlplug } & \multicolumn{2}{|c|}{ J. W. Construction Holding } \\
\hline $\mathrm{TV}=/=>\mathrm{SR}$ & $5.2932 *$ & $\mathrm{TV}=/=>\mathrm{SR}$ & $2.6672 * * *$ \\
\hline \multicolumn{2}{|l|}{ Redwood } & $\mathrm{SR}=/=>\mathrm{TV}$ & $7.5518^{*}$ \\
\hline $\mathrm{TV}=/ \Rightarrow \mathrm{SR}$ & $9.7730 * *$ & \multicolumn{2}{|l|}{ LC Corp } \\
\hline $\mathrm{SR}=/=>\mathrm{TV}$ & $3.7854 * *$ & $\mathrm{SR}=/ \Rightarrow>\mathrm{TV}$ & $4.3682 * *$ \\
\hline \multicolumn{2}{|l|}{ Relpol } & \multicolumn{2}{|c|}{ Ronson Development } \\
\hline $\mathrm{SR}=/=>\mathrm{TV}$ & $2.5622 * * *$ & $\mathrm{TV}=/=>\mathrm{SR}$ & $2.3266^{* * *}$ \\
\hline \multicolumn{2}{|l|}{ Ursus } & \multicolumn{2}{|c|}{ Soho Development } \\
\hline $\mathrm{SR}=/=>\mathrm{TV}$ & $33.3970 *$ & $\mathrm{SR}=/=>\mathrm{TV}$ & $2.3315 * * *$ \\
\hline \multicolumn{2}{|c|}{ Urządzeń Kotłowych Stąporków } & \multicolumn{2}{|l|}{ Wikana } \\
\hline $\mathrm{SR}=/=>\mathrm{TV}$ & $2.8310 * * *$ & $\mathrm{SR}=/=>\mathrm{TV}$ & $4.7500 *$ \\
\hline \multicolumn{4}{|l|}{ Zpue } \\
\hline $\mathrm{SR}=/=>\mathrm{TV}$ & $7.0672 *$ & & \\
\hline
\end{tabular}

Source: Authors' calculations. Note: *,** and *** denote significance at the $1 \%, 5 \%$ and $10 \%$ levels. TV denotes trading volume and SR denotes stock returns. 


\section{Conclusion}

The objective of the paper was to examine the relationship between the trading volume and stock returns of selected companies listed on the Warsaw Stock Exchange during 2008 - 2018. The findings of the Granger causality test show different type of results, which is consistent with Gündüz and Hatemi-J (2005). First, the Granger causality between trading volume and stock returns is consistent with findings of Bohl and Henke (2003) and there could be identified some reason for these results. The factor that could affect results was the values of correlation coefficients, which show the co-movements of variables were not strong. This could be related to the fact the Granger causality between trading volume and stock returns is prevailed on more liquid titles but it was not a rule. And there could have existed different factors that affect the relationship between trading volume and stock prices, for example sentiment of investors, the rational and non-rational investment decisions, the tradition of the companies on the market, the position and importance in the industry, the interest of investors about individual stock titles, the perspective of the sectors and individual companies, the sector cycle, competitors, the size of the market, market liquidity, the nature of the trend, relatively stable development of business activities of the companies, quality of legislative regulation of sectors, the perspective of the sectors and individual companies, the sector cycle, competitors, and the size of the market.

Then, there was also detected causality in the opposite direction going from the stock returns on trading volume, which showed for example findings of Brüggemann et al. (2014). The existence of Granger causality in opposite direction going from the stock returns on trading volume could be caused by fact the stock prices demand is influenced by many factors, for example by macroeconomic variables, industry specifics, corporate governance factors, financial characteristics of companies. The findings of a bidirectional causality between stock returns and volume and causality in opposite direction in many observations and sometimes discrepancy with correlation analysis across analysed sectors could be related to agency problems which are particularly severe in the transition economies and former economies in transition, the lack of informational efficiency and level of trading regulations, as Gündüz and Hatemi-J (2005) argues. However, investigating the relationship between various market variables and stock prices or stock returns certainly requires further future research.

There was also determined no relationship between trading volume and stock returns that showed results of Gurgul et al. (2005) and Gündüz and Hatemi-J (2005). The findings of no relationship could be caused by lower liquidity of titles and related lower interest of investors, shorter existence of companies, lower markets share, lower importance in the industry, and question of future development of companies. For analysed sectors, the results show, both the correlation and Granger causality was determined in most cases for investment and real estate sectors that could be caused, for example by higher share on GDP of these sectors in comparison with other analysed industries, market position of companies, interest of investors about finance sector for portfolio diversification, industry life cycle, competition in industry, and business cycle sensitivity. Simultaneously, in sectors (investment industry and real estate industry) where is evident a higher number of observations of Granger causality between trading volume and stock returns, there is usually determined lower number of observations of causality in opposite direction going from stock returns on trading volume, and vice versa. It seems that there is better perspective of using trading volume as support tool of technical analysis in investment and real estate industry then in food, clothing and machine industry. 


\section{Acknowledgement}

Publication of this paper was supported by the institutional support "VŠE FPH IP300040". The support is greatly acknowledged.

\section{References}

[1] BOHL, M. T. and H. HENKE, 2003. Trading volume and stock market volatility: The Polish case. International Review of Financial Analysis, 12(5), 513 - 525. ISSN 10575219.

[2] BRÜGGEMAN, R., M. GLASER, S. SCHAARSCHMIDT and S. STANKIEWICZ, 2014. The Stock Return - Trading Volume Relationship in European Countries: Evidence from Asymmetric Impulse Responses. Working paper series $2014-24$, University of Konstanz [online]. 16 December 2014 [vid. 1 October 2019]. Available from: <https://econpapers.repec.org/paper/knzdpteco/1424.htm>.

[3] CIPRA, T., 2008. Finanční ekonometrie. 1. vyd. Praha: Ekopress. ISBN 978-80-8692943-9.

[4] DUMITRESCU, E. I. and CH. HURLIN, 2012. Testing for Granger non-causality in heterogeneous panels. Economic Modelling, 29(4), 1450 - 1460. ISSN 0264-9993.

[5] GPW, 2019. GPW Main Market [online] [vid. 1 June 2019]. Available from: $<$ https://www.gpw.pl/list-of-companies>.

[6] GRANGER, C. W. J., 1969. Investigating Causal Relations by Econometric Models and Cross-spectral Methods. Econometrica, 37(3), 424 - 438. ISSN 0012-9682.

[7] GURGUL, H., P. MAJDOSZ and R. MESTEL, 2005. Joint Dynamics of Prices and Trading Volume on the Polish Stock Market. Managing Global Transitions, 3(2), 139 156. ISSN 1854-6935.

[8] GÜNDÜZ, L. and A. HATEMI-J, 2005. Stock Price and Volume Relation in Emerging Markets. Emerging Markets Finanace and Trade, 41(1), 29 - 44. ISSN 1558-0938.

[9] HIEMSTRA, C. and J. D. JONES, 1994. Testing for Linear and Nonlinear Granger Causality in the Stock Price-Volume Relation. The Journal of Finance, 49(5). 1639 1664. ISSN 0022-1082.

[10] HUI-WEN, Y., 2006. Discussion on How to Do Granger Causality Test. Journal of the Postgraduate of Zhongnan University of Economics and Law [online]. 14 May 2006 [vid. 9 October 2019] Available from: <http://en.cnki.com.cn/Article_en/CJFDTotalZNCZ200605006.htm>.

[11] CHEN, G., M. FIRTH and O. M. RUI, 2001. The dynamic relation between stock returns, trading volume and volatility. Financial Review, 36(3), 153 - 173. ISSN 07328516.

[12] IQBAL, H. and T. RIAZ, 2015. The Empirical Relationship Between Stock Returns, Trading Volume and Volatility: Evidence from Stock. Research Journal of Finance and Accounting, 6(13), 180 - 192. ISSN 2222-2847.

[13] LEE, B. S. and O. M. RUI, 2002. The dynamic relationship between stock returns and trading volume: Domestic and cross-country evidence. Journal of Banking\&Finace, 26(1), 51 - 78. ISSN 0378-4266.

[14] MUSÍLEK, P., 2002. Trhy cenných papírů. 1. vyd. Praha: Ekopress. ISBN 80-86119-556. 
[15] NEUSSER, K., 2016. Time Series Econometrics. 1st ed. Switzerland: Springer International Publishing. ISBN 978-3-319-32861-4.

[16] PESARAN, M. H., 2015. Time Series and Panel Data Econometrics. 1st ed. Oxford: Oxford University Press. ISBN 978-0-19-875998-0.

[17] ROTILA, D. M., M. ONOFREI and A. M. ANDRIES, 2015. The Relation Between Stock Returns, Trading Volume and Return Volatility of the CEE Banks. Transformation in Business \& Economics, 14(2A), 478 - 497. ISSN 1648 - 4460.

[18] SIMS, C. A., 1975. Exogeneity tests and multivariate time series: Part 1, Center of Economic Research, Discussion paper 75-54 [online]. June 1975 [vid. 10 October 2019]. Available from: <https://conservancy.umn.edu/bitstream/handle/11299/54806/1/197554.pdf>.

[19] TUDOR, C., 2009. The Impact of Trading Volume on Stock Returns and Volatility on the Romanian Capital Market. SSRN [online]. 14 Januar 2009 [vid. 10 October 2019] Available from: <https://papers.ssrn.com/sol3/papers.cfm?abstract_id=1327687>.

[20] VESELÁ, J., 2011. Investování na kapitálových trzích. 2. vyd. Praha: Wolters Kluwer ČR. ISBN 978-80-7357-647-9.

[21] ZOU, C. and J. FENG, 2009. Granger Causality vs. Dynamic Bayesian Network Inference: A Comparative Study. BMC Bioinformatics, 10(1), 1 - 12. ISSN 1471-2105. 